\title{
Memanusiakan orang yang serakah Ditinjau dari Perspektif Teori Humanistik
}

\author{
Adolpin Saltin Tangdilintin, Heri Kurniawan, Lidia Monika \\ Maimakal, Yois Logo \\ (adolpinsaltint@gmail.com ) \\ (herikurniawan1312@gmail.com ) \\ (lidiamonika1606@gmail.com ) \\ (masthopiusmasthopius@gmail.com )
}

\begin{abstract}
Abstrak
Teori humanistik merupakan teori yang memberikan penjelasan tentang bagaimana memanusiakan manusia dan mengaktualisasikan kemampuan untuk menerapkan dalam lingkungan sekitar. Teori ini memberikan atau menekankan tentang kognitif dan afektif dalam mempengaruhi sebuah proses yang ada. Dalam menerapkan teori humanistik harus mempunyai kemampuan untuk menggali dan merasakan apa yang menjadi masalah dan harus diselesaikan dalam teori humanistik ini. Lewat teori ini pengajar harus memahami terlebih dahulu apa yang akan dia sampaikan kepada muridnya karena jika seorang pengajar sendiri tidak memahami apa yang dia sampaikan otomatis itu akan berpengaruh pada setiap pribadi murid yang diajarnya oleh karena itu dengan Teori humanistik memberikan sumbangsi kepada seorang pengajar untuk diterapakan kepada muridnya agar murid tersebut dapat menerapkannya kembali kepada orangorang yang ada disekitarnya. Teori humanistik juga memberikan sebuah pengajaran yang nyata baik secara emosional maupaun secara rasional untuk memperbaiki hubungan antara seorang pengajar dengan murid. Tujuan penulisan ini adalah untuk membantu para pengajar agar lebih mengetahui akan bagaimana memanusiakan murid yang diajarnya baik itu lewat materi maupun tindakan lewat lingkungan yang ada disekitarnya.

Menurut penelitian penulis mengatakan bahwa banyak anak yang saat ini kurang memahami akan materi karena kurangnya kerja sama antara pengajar dan muridnya, karena kebanyakan para pengajar hanya mengunakan satu metode dalam mengajar sehingga hal itu mempengaruhi cara berpikir siswa menjadi lemah padahal yang kita tahu bahwa proses belajar mengajar adalah memanusiakan orang yang di ajar lewat lingkungan disekitar. Kesimpulannya adalah memanusiakan orang lewat tindakan dengan menggunakan lingkungan yang ada di sekitar.
\end{abstract}

Kata-kata kunci: humanistik, menghargai, tindakan, lingkungan 


\section{Pendahuluan}

Maslow mengatakan bahwa Teori Humanistik adalah teori yang memanusiakan manusia itu dapat menerapkan dalam kehidupannya dan mengaktualisasikan dalam lingkungan sekitar. Dalam proses memanusiakan manusia yang diperlukan adalah kesabaran agar bisa membimbing orang dengan baik sehingga mereka mengerti apa di sampaikan baik itu lewat materi dan juga praktek.

Pendidikan harus ditekankan pada potensi peserta didik untuk mengembangkan kepribadian, kebebasan untuk memilih dan menentukan nasib mereka sendiri dan melalui proses pembelajaran, pendidikan sudah seharusnya dapat membantu pemenuhan kebutuhan individual. ${ }^{1}$

lewat proses latar belakang dalam pemelihan judul ini adalah dapat di lihat dari bagaimana seorang menggunakan suatu hak untuk kepentingan pribadinya tanpa memikirkan orang yang ada disekitarnya. Dan dalam pemilihan judul ini penulis mengambil kisah anak yang hilang untuk menjadi penghubung untuk diterapkan dalam penulisan ini karena di lihat dari tindakan yang di lakukan oleh anak sulung dan anak bungsu ini adalah tindakan yang serakah yang hanya mementingkan satu golongan atau kepentingan pribadi.

Dalam pemilihan judul ini bagaimana kita tahu bahwa seorang ayah memanusiakan anaknya dengan dengan cara yang berbeda tetapi ketika si anak tumbuh dewasa dan tahu akan yang baik dan yang buruk, si anak lebih dominannya kepada lingkungan yang ada di sekitar. Lingkungan adalah salah satu proses dimana orang bisa belajar segala hal namun ada hal dimana lingkungan tersebut membawa orang pada kehancuran, itulah yang dialami oleh anak bungsu meskipun dia diajarkan hal-hal yang baik oleh ayahnya tetapi ketika dia berada di lingkungan dia berubah menjadi orang yang sangat egois dan serakah.

Terkadang kita anggap bahwa lingkungan adalah tempat belajar selain di rumah dan sekolah, namun lingkungan juga

Seperti yang Maslow katakan bahwa manusia itu pada dasarnya adalah baik, atau tepatnya netral dan menurut perspektif humanistik, kekuatan jahat atau merusak yang ada pada manusia itu adalah hasil dari lingkungan yang buruk dan bukan merupakan bawaan ${ }^{2}$. Maslow bukan hanya berbicara tentang itu tetapi di juga membedakan bagaimana manusia itu dari sini kita bisa melihat bahwa manusia itu menjadi rusak, serta egois dan juga serakah adalah pengaruh dari lingkungan yang buruk.

Tujuan penulisan ini untuk membantu setiap orang dalam mengajar dan mendidik orang-orang agar bisa mengaktualisasikan dalam perspektif Humanisme.

\footnotetext{
${ }^{1}$ Siti mumun muniroh jurusan tarbiyab sekolah Tinggi Agama Islam Negeri (STAIN) pekalongn, Jl.Kusumabangsa No.9 email: moen_maunk@yahoo.com, "Penerapan Aliran Psikologi Humanistik" Pekalongan : jurnal Forum Tarbiyah (NO. 1 Vol. 91 januari 2011), 47.

${ }^{2}$ E Koeswara, Teori-teori kepribadian (Bandung:PT Eresco 1991),117.
} 
Dalam perspektif humanisme ini membantu orang-orang untuk mengembangkan pengetahuan yang ada, pada diri setiap orang dan memberi kesempatan agar dapat mengerti dan memahami individu sendiri sehingga dapat memgembangkan potensipotensi yang ada pada diri setiap orang.

\section{Kajian Teori}

Teori Maslow didasarkan pada asumsi bahwa didalam diri individu ada dua hl yaitu pertama, suatu usaha yang positif untuk berkembang kedua, kekuatan untuk melawan

Atau menolak perkembangan itu. maslow berperilaku dalam upaya untuk memenuhi kebutuhan yang bersifat hirarkis. maslow membagi kebutuhan-kebutuhan (needs) manusia menjadi tuju hirarki, bila seseorang telah memenuhi kebutuhan pertama, seperti kebutuhan filosifis, barulah ia dapat menginginkan kebutuhan yang terletak diatsnya, ialah kebutuhan mendapatkan rasa aman dan seterusny. Hirarki kebutuhan manusia menurut maslow yang penting dan harus diperhatikan oleh pengajar ketika ia mengajar orang. Dan perhatian motivasi ini berkembang kalau kebutuhan dasar orang bekum terpenuhi. ${ }^{3}$

Pengunaan nas Alkitab ini karena disini ada teori humanistik yang terdapat dalam pembahasan ayat-ayat ini seperti anak bungsu pergi berfoya-foya dan menghabiskan hartanya kemudian dia kesusahan dan dia bekerja sebagai seorang penjaga babi dan disisni lah dia menyadari akan kesalahan dan yang diperbuatnya. disini sangat jelas karena teori humanistik adalah teori yang memanusiakan manusia dan bagaimana seorang dapat mengaktualisasikan dalam lingkungan itulah yang dilakukan oleh anak bungsu menyadari kesalahannya lewat keadaan lingkungan yang di mana dia berada.

Pendekatan teori humanistik dengan dengan judul sangat berkaitan sekali karena kalau kita baca keseluruhan dari pada ayat-ayat tersebut kita bisa melihat bahwa kedua anak ini serakah, mengapa dikatakan serakah kerena mereka hanya mau harta kekayaan ayahnya tetapi lebih dominannya ke anak yang bungsu karena di mana ia meminta bagiannya dan kemudian pergi berfoya-foya dan menghabiskan seluruh harta yang menjadi miliknya. disini sangat jelas bahwa anak bungsu adalah serakah atas harta ayahnya. Dia egois karena dia mempedulikan orang yang disekitarnya termasuk ayahnya. Dan adanya ketidakpuasan dalam dirinya sehingga dia memaksa agar memberikan harta yang menjadi miliknya dan pergi menghabiskan tanpa memikirkan orang lain lain dan tanpa memikirkan konsesuensi dari apa yang dia lakukan.

\section{Metode}

Metode penulisan makalah ini adalah analisis data kualitatif yaitu menjelaskan data-data yang dikumpulkan sesuai dengan teori-teori yang dirangkum dari hasil penelitian. ${ }^{4}$ Selanjutnya dengan menggunakan model pembelajaran kooperatif berbasis

\footnotetext{
${ }^{3}$ Noviana suprobo. "Teori belajar Humanistik", Journal : 3.

${ }^{4}$ Hengki Wijaya and Helaluddin Helaluddin, Analisis Data Kualitatif Sebuah Tinjauan Teori \& Praktik (Makassar: Sekolah Tinggi Theologia Jaffray Makassar, 2019).
} 
media sosial. ${ }^{5}$ Dengan menggunakan metode 5P (Belajar berarti berubah) ${ }^{6}$ Selanjutnya secara deskriptif dijelaskan $5 \mathrm{P}$ dalam praktik kelas Bersama dengan mahasiswa lainnya.

Bagian ini berisih langkah-langkah $5 \mathrm{P}$ secar detil yang akan dilakukan dan tindakan aktivitas belajar dan Tujuan pembelajaran terjabarkan dalam bagian ini.

\section{Penghubung}

Menggunakan Video tentang anak yang hilang dalam Lukas 15:11-32, sebagai penghubung kedalam teori belajar humanistik yang memanusiakan manusia. Ketika melihat video tersebut ada hal yang perlu diperbaiki dalam hidup manusia seperti judul saat ini bahwa harus memanusiakan manusia yang serakah yang ditinjau dari perspektif Humanistik. Manusia yang serakah memiliki sifat yang tidak puas akan apa yang dia miliki oleh sebab itu mereka selalu berusaha untuk menghidupi dirinya dengan cara apapun. Seperti yang kita lihat dalam video anak yang hilang karena ketidakpuasan akan hidupnya sehingga ia meminta bagian yang menjadi harta miliknya untuk dia pakai sendiri untuk berfoya-foya untuk kepuasan hidupnya sendiri tanpa berfikir panjang kedepan. Banyak sekali orang yang seperti itu.

Dalam teori maslow juga berkata demikian: Kebutuhan jasmaniah seperti makan, minum, tidur, dan sex menuntut sekali untuk dipuaskan. Apabila kebutuhan ini terpuaskan, maka muncullah kebutuhan keamanan seperti kebutuhan akan kesehatan dan kebutuhan terhindar dari bahaya dan bencana ${ }^{7}$. Cat 4 Disini sangat terlihat bahwa kesenangan manusia ketika kebutuhan jasmania terpenuhi.

\section{Pelajaran}

Yang di maksud dalam pembelajaran disini dalam teori humanistik adalah mau belajar tanpa diberikan arahan, sadar akan apa yang menjadi tugas utamanya, dan dia belajar akan perubahan yang ada. Teori ini dikemukakan oleh Carl R. Rogers ${ }^{8}$. Cat 5 Pembelajaran ini berguna untuk semua orang baik itu pendidik maupun itu yang di didik.ketika kita menonton video tentang anak yang hilang ada banyak hal yang dapat kita pelajari dari video tersebut. pertama kita bisa belajar dari anak bungsu yang sadar akan kesalahannya. Kedua kita bisa belajar dari sang ayah ia mampu untuk memaafkan anaknya. Dari hal tersebut kita mengetahui bahwa hal ini bisa dikatakn memanusiakan manusia dan mampu mengubah setiap keadaan menjadi baik lag.

5 Hengki Wijaya and Arismunandar Arismunandar, "Pengembangan Model Pembelajaran Kooperatif Tipe STAD Berbasis Media Sosial,” Jurnal Jaffray 16, no. 2 (October 6, 2018): 175-96, https://doi.org/10.25278/jj71.v16i2.302.

6 Roland Walker, "Learning That LASTS," n.d., https://wycliffe.fi/wpcontent/uploads/2018/12/intro-to-learning-that-lasts-walker.pdf.

7 Ratna Syifa'a Rachmahana1Psikologi Humanistik dan Aplikasinya dalam Pendidikan Jurnal pendidikan eltarbaw(NO. 1. VOL. I. 2008), 100.

${ }^{8}$ Ibid 


\section{Perubahan}

Perubahan adalah ketika seseorang mau memperbaiki semua kesalahan yang dilakukan baik dalam pola pikir dan tingkah laku. Dari perubahan ini dapat dirasakan dan mengetahui sejauh mana seseorang dapat berubah lewat keadaan yang di alami dan bagaimna cara menyikapi hal tersebut. perubahan yang ada dalam teori ini bukan perubahan yang sesaat saja tetapi akan terus berlanjut selama manusia hidup dimuka bumi ini dan pengalaman yang telah membuat hidup mereka berubah menjadi panutan atau teladan dan sahabat yang baik dalam hidup mereka.

Perubahan menjadikan banyak orang untuk hidup dalam ketentraman baik secara pribadi maupun dalam lingkungan keluarga dan masyarakat.perubahan adalah hal yang ditunggu oleh bbanyak orang karena setiap orang yang berubah akan membawa dampak yang besar bagi setiap keadaan.

\section{Penerapan}

Penerapan adalah setelah kelompok menampilkan video tentang perumpamaan tentang anak yang hilang adalah setiap orang yang menuliskan bahkan mendalami video, itu untuk menuliskan apa yang akan menjadi komitmen mereka untuk mereka lakukan dalam kehidupan mereka baik ketika berada dalam lingkungan sebagai mahasiswa maupun ketika sudah terjun dalam sebuah pelayanan yang Tuhan percayakan.

\section{Hasil dan Pembahasan}

Hasil yang diperoleh dari berbagai pengalaman, aktivitas belajar, dan keterkaitan dengan teori yang digunkan.

Dari hasil peresentasi kelompok didalam kelas mengenailam teori humanistik video anak yng hilang ini, mereka semua banyak yang diberkati, ada yang mengatakan bahwa memanusiakan manusia itu dalam teori humanistik ketika difikirkan tidaklah mudah karena yag berpesan disini adalah tindakan yang nyata sehingga ada yang berkata bahwa kehidupan yang dulu dan yag sekarang sangatlah berbeda, karena dulu saya disebut manusia tetapi sifat saya bukan manusia dan sekarang baru saya bisa dikatakan manusia karena sudah bisa mengubah diriku menjadi manusia yang seutuhnya yang telah mengenal Allah.

Dalam pengajaran Humanistik ini banyak hal yang harus diubah oleh karena itu teori belajar humanistik menjadi solusi karena memunculkan proses-proses pendidikan yang dibutuhkan menurut Huglund (tanpa tahun) yakni proses-proses yang menyenangkan (excitement) dan menantang (wonderment) dengan kegiatan-kegiatan penemuan (discovery) dan kreasi/karya cipta ${ }^{9}$.

9 Oleh: Mita Hapsari Jannah1 , Suyoto2 (1,2)Dosen Universitas Muhammadiyah PurworejoMita_Umpwr@protonmail.com(1), suyoto.ump@gmail.com(2), “Teori Humanistik Dalam Multimedia Pembelajaran Bilangan Bulat" semarang : Jurnal Karya Pendidikan Matematika Vol 5 No 2.67 


\section{Kesimpulan}

Humanistik berfokus kepada tingkat akhir yaitu memanusiakan manusia. dengan membawa setiap indifidu dengan pengalaman akan lingkungan sekitar dan lewat semua itu ada perubahan yang dhasilkan.

Dengan demikian penulis telah menyelesaikan degan penuh bangga dan harapan dari penulis bahwa kiranya lewat pengkajian materi yang telah dibahas kiranya senantiasa membantu dan menolong kita dalam meninjau sesuatu

\section{Kepustakaan}

Mumun, muniroh, Siti. "Penerapan Aliran Psikologi Humanistik": jurnal Forum

Tarbiyah, NO. 1 Vol. 9 (1 januari 2011): 47.

Koeswara E, “Teori-teori kepribadian” (Bandung:PT Eresco 1991),117.

Suprobo, noviana. "Teori belajar Humanistik", Journal.: 4

Syifa'a, Rachmahana1, nanda. "Psikologi Humanistik dan Aplikasinya dalam

Pendidikan,” Journal pendidikan eltarbaw NO. 1. VOL. I. (2008): 100.

Suyoto, Jannah, Hapsari, Mita. "Teori Humanistik Dalam Multimedia Pembelajaran

Bilangan Bulat" "Teori Humanistik Dalam Multimedia Pembelajaran Bilangan

Bulat" semarang : Jurnal Karya Pendidikan Matematika, Vol. 5 No. 2.67.

Walker, Roland. "Learning That LASTS," n.d. https://wycliffe.fi/wpcontent/uploads/2018/12/intro-to-learning-that-lasts-walker.pdf.

Wijaya, Hengki, and Arismunandar Arismunandar. "Pengembangan Model Pembelajaran Kooperatif Tipe STAD Berbasis Media Sosial.” Jurnal Jaffray 16, no. 2 (October 6, 2018): 175-96. https://doi.org/10.25278/jj71.v16i2.302.

Wijaya, Hengki, and Helaluddin Helaluddin. Analisis Data Kualitatif Sebuah Tinjauan Teori \& Praktik. Makassar: Sekolah Tinggi Theologia Jaffray Makassar, 2019. 